\title{
FEDERAL JUDGES AND QUASI-JUDGES.
}

Chief-Justice Jay, three years after the adoption of the Constitution; laid down the proposition "that by the Constitution of the United States, the Government thereof is divided into three distinct and independent branches, and that it is the duty of eacin to abstain from and to oppose encroachments on either."' These branches are the legislative, executive and judicial. The distinction has always been treated in theory as fundamental, and for a long time its preservation was treated in actual practice also as an object of great solicitude. The early amendments to the Constitution gave additional guarantees that the judicial sphere should not be invaded by the legislature or by the executive. The judiciary, on the other hand, maintained their right to exemption from non-judicial work. The ChiefJustice, in the case just quoted, laid down the further proposition: "That neither the legislative nor the executive branches can constitutionally assign to the judicial any duties but such as are properly judicial and to be performed in a judicial manner." Upon the same principle the executive departments claimed, and the judiciary conceded that the executive discretion should not be guided nor interfered with in any way by judicial process. Even when the duties of the executive were of the simplest and clearest character, the right of the judiciary to compel their performance was stoutly resisted. The controversy, which was commenced by Jefferson and Marshall at the beginning of the century, was not settled until the time of Van Buren." No student of our form of government can afford not to read the vigorous exposition of this fundamental distinction by Postmaster-General Kendall and Attorney-General Butler in the lower court in Kendall's case, its more qualified statement by the Attorney-General in the same case at the bar of the Supreme Court, or the opinions of the Supreme Court Justices in this case and in that of Secretary Paulding which immediately followed, and which have resulted in confining the remedy of mandamus, in the Federal

\footnotetext{
1 Hayburn's Case, 2. Dall. 410, note.

2 Marbury v. Madison, I Cr. 137; United States v. Kendall, 5 Cr. C.C. I63; Kendall $v$. United States, I2 Pet. 524; Decatur v. Paulding, I4 Pet. 497.
} 
courts, within limits narrower, probably, than those recognized in any other system of jurisprudence of English origin.

In order to secure the entire independence of the judiciary, its members were given practically a life tenure. They were not even to be retired compulsorily for old age. They were to be removed from office only by a two-thirds vote of the United States Senators, sitting as a Court of Impeachment. It was intended thus to ensure fearlessness in the performance of judicial duties, by providing that the tenure of judicial office should be made secure before its incumbent should be called upon to render any decision.

It may be interesting to consider how thoroughly this constitutional theory has proved complete. It will be found that all Fedcral Judges, except the justices of the Supreme Court of the United States, are practically removable; that among one class of them removals are of continual occurrence; and that it is even not impossible for a man to occupy the highest judicial position in the nation, and then to lose it by reason of an unpopular decision. It will be found that all judges may be charged with some duties strictly executive in nature, while some judges may be charged with executive duties to an indefinite extent. It will be found that a large department of work strictly judicial in its nature may be confided either to the judicial or to the executive branch, at the will of Congress; which has gone even so far in practice as to grant a right of appeal from the judiciary to the executive or vice vicrsí.

Mr. Justice Curtis has defined judicial acts, in an "enlarged" sense, as "all those administrative duties the performance of which involves an inquiry into the existence of facts and the application to them of rules of law." He instances among such acts that of the President in calling out the militia; but this gives the term an enlarged definition indeed, for when the President, having been asked to call out the militia, has ascertained the facts and satisfied himself about his legal powers, there still remains a question of expediency to be dctermined, and this element of expediency makes the case one calling rather for executive than for judicial discretion, although a discretion sometimes exercised by courts, as in the care of trust property or of property attached. The definition would become a stricter one by excluding the element of expediency and postulating "all the elcments of a civil case-a complainant, a defendant, and a judge-actor,

3 Mlurray's Lessee $\pi$. Hoboken Land and Improvement Co., IS How. 272, 280. 
reus et judcx." It is not necessary to the essence of a judicial act that it be performed by a person bearing a judicial title. Thus the Constitution expressly provides for a Court of Impeachment composed of United States Senators, and provides, also, that each House of Congress shall be "the judge of the elections, returns, and qualifications of its own members."

Passing by these exceptional instances and those afforded by military and naval tribunals, judicial discretion, as above defined, in our Federal Government, is exercised by at least three classes of officers; first, judges appointed under the judiciary article of the Constitution; second, judges appointed under the territorial provision of the Constitution; and, third, quasijudicial officers deputed by Congress for the decision of controversies to which the United States is a party. These classes will now be considered separately.

I. Judges appointed under the judiciary article.-In theory, as we have said, these officers are irremovable except upon conviction in a Court of Impeachment. They hold by a tenure whose dignity is now very rare. They are commonly spoken of as holding for life.

Nevertheless, in every court save one, if a sufficient number of the judges become obnoxious to the other branches of the Government, they can be got rid of. The Constitution provides that the judicial power "shall be vested in one Supreme Court, and in such inferior courts as the Congress may from time to time ordain and establish." As the Constitution has been practically construed, Congress may abolislı an inferior court as well as establish it. This has actually been done in two noted instances. The first occurred in 1802 . In the last weeks of the Federalist administration, a bench of United States Circuit Judges had been established by law, and had been filled by Federalist appoint. ments. The political effect of this, so far as we may judge from the Congressional debates, had been overlooked in the excitement of the pending contest for the Presidency between Jefferson and Burr. The immense power which the Federal judges could exercise is construing the constitution and laws was, however, coming into general recognition, and the Republican party, on assuming the control of the legislative and executive branches of the Government, saw what a weapon had been placed, perhaps for a generation to come, in the hands of the opposition. The new judges could not be removed. The new court, therefore, was

- Fong Yue Ting $v$. United States, I49 U. S. 698, 729. 
abolished, after a great constitutional debate. The judges united in a memorial protesting against the proceeding; but they were even denied a resort to quo warranto. ${ }^{5}$ In 1863 a similar method was adopted for the purpose of getting rid of the judges of the United States Circuit Court for the District of Columbia. Again the constitutional question was raised in Congress. Some claim was made that this was only a territorial court, and, therefore, not protected by the judiciary article of the Constitution; but Senator Ira Harris of New York, who was in charge of the measure, and had himself long held high judicial office, put it squarely on the ground that Congress had the right to abolish any inferior court. The bar of the District protested; but the court was abolished, and the present Supreme Court of the District of Columbia, composed of new judges, took its place.

The Supreme Court of the United States was established by the Constitution itself, and therefore cannot be abolished. Its membership can be diminished only by voluntary retirement, by impeachment, or by death; thus giving Congress the power, as in 1866 , to make the diminution permanent. Congress, however, may increase the membership. as was done in 1807,1837 and 1869. In this respect it is similar to the highest British tribunal, the House of Lords. If popular feeling against its members or their decisions at any particular time become sufficiently strong, it can be "packed" by increasing its numbers sufficiently to control its vote. The House of Lords, although sometimes threatened, has not been actually "packed" for nearly two centuries; and the Supreme Court has never even been openly threatened, so far as I am aware, although it has been often charged that President Grant in effect "packed" the court in 1870 in order to obtain the overruling of one of its decisions, and although such an intent during the present year has been claimed to be hidden in the wording of the platform of one of the great political parties. The writer has elsewhere argued that the chief bulwark against this danger has been the general practice of the court in adhering to its decisions upon political questions notwithstanding changes of membership." It is possible, however, that a man may sit for a while upon the Supreme Court as upon any inferior court, and yet be without the consti-

s Annals of Congress, January 27 and February 3, 1803, pp. 30-32, 51-78, 427-44r.

- Political Dangers of the Income Tax Decision. "The Forum," July, 1895, p. 529. 
tutional guaranty of independence. Whaterer offices become vacant during a recess of the Senate, the President has power to fill "by granting commissions which shall expire at the end of their next session." Under this provision John Rutledge of South Carolina was appointed Chief-Justice of the United States Supreme Court by President Washington during a recess of the Senate, and actually presided at the August term, 1795. The Senate subsequently refused to confirm his nomination, some say on the ground of insanity, some say for political reasons. The precedent has been attacked as dangerous and as violating the spirit of the Constitution; but it has not infrequently been followed, at least in the case of inferior courts.

Space does not permit a discussion here of the limits within which the courts may interfere with Federal executive officers by mandamus, by injunction or otherwise. Curious questions have arisen as to how far Congress may go in imposing quasiexecutive duties upon the judgés. The first and second Congresses attempted to impose upon the Circuit Courts the duty of examining into applications for invalid pensions and reporting their conclusions thereon to the Secretary of War, to whom appellate jurisdiction was given. The judges held unanimously that such business was not judicial, and that the statutes were nullities.' Congress subsequently provided that the United States District Judge for Florida should adjudicate upon certain claims of the United States in that District, the adjudication, however, to be subject to review by the Secretary of the Treasury. The Supreme Court unanimously held that this was not judicial bu'siness, being "entirely alien to the legitimate functions of a juclge or court of justice;" and that if the judgre could properly act under the statute at all, he "could not act in a judicial character as a court nor as a commissioner." Grave doubt was expressed as to the constitutionality of the law, but this question was not presented and therefore not decided. ${ }^{8}$

Similar laws are now upon the statute book, and are administered by the judges without question. Thus it is common for a district judge to take evidence upon the question of good faith after the imposition of a penalty or forfeiture for violation of the tariff laws; his findings of fact being transmitted to the Secretary of the Treasury, who is not, however, bound thereby.' So,

'Hayburn's Case, supra; Únited States $v$. Yale Todd, 13 How, 52, note.

- United States $v$. Fericira, 13 How. 40, 5 r.

- Anti-Moiety Act of June 22, 1874, \$§ 17, 18. 
also, the district judges often report the facts upon applications of district attorneys for compensation even for services rendered out of court. ${ }^{10}$ Under a similar statute, however, whereby the judge is called upon to certify the value of an informer's services, subject to review by the Secretary of the Treasury, Judge Maxey of the Western District of Texas has recently held that the power attempted to be conferred is not judicial, and that the judges accordingly are without jurisdiction in the premises." No attempt appears to have been made to obtain a review of this decision.

The Constitution itself recognizes, however, that the courts may properly perform duties of an executive nature, and accordingly provides expressly that Congress may vest in them "the appointment of such inferior officers as they think proper." The United States Commissioners and the Clerks of Court, who belong to the executive branch of the government, are appointed under this provision, and District Attorneys and Marshals receive in the same way ad interim appointments. A controversy recently arose over the right of Congress to call upon the judges to enforce the attendance of witnesses before administrative officers. In the lower courts the existence of this power was denied. ${ }^{12}$ It was sustained, however, in 1894 , in the Supreme Court by a vote of five to three in the case of the Interstate Commerce Commission. ${ }^{13}$ Notwithstanding that decision, one of the district judges still maintained that he could not be required to enforce the attendance of witnesses before special examiners of the Pension Bureau, but the Supreme Court, on application of the Comnrissioner of Pensions, granted a writ of iatundamus compelling him to do so."

II. Territorial Judgrcs.-The judicial power of the United States is placed by the Constitition in the hands of judges who "shall hold their offices during good behavior." Nerertheless the people of the Territories and the vast properties there situated are under the protection of judges who are appointed for four years only and who are removable by the President. This

${ }^{10}$ In re District Attorney, 23 Fed. Rep. 26: Cnited States v. Bashaw, 152 U. S. 436 .

"Ex parte Riebling, 7o Fed. Rep. 310.

12 In rc Pac. R. R. Commission, 32 Fed. Rep. 251; In re MlcLean, 37 Fed. Rep. 648; In re Interstate Commerce Commission, 53 Fed. Rep. 4 Sr.

is Interstate Commerce Commission 2 . Brimsull, 15 t U. S. $4+7$.

it In re Lochren, Ió3 U. S. 6)2. 
practice has existed since the earliest days, and has been repeatedly approved by the Supreme Court." These judges have been termed "legislative courts" as distinguished from "constitutional courts." Their existence is justified under that sweeping constitutional provision which gives to Congress "power to dispose of and make all needful rules and regulations respecting the territory or other property belonging to the United States." For the same reason that these judges are not protected with a life tenure, they are also not protected from the imposition of duties non-judicial in nature. They are not judges at all in the constitutional sense of the term, but are officers to whom are delegated such judicial powers as must necessarily be performed by somebody within the Territory.

A similar constitutional provision authorizes Congress "to exercise exclusive legislation in all cases whatsoever over such district (not exceeding ten miles square) as may by cession of particular States and the acceptance of Congress become the seat of the Government of the United States." It is an unsettled question whether it is this provision, or the judiciary article of the Constitution, which lies at the hasis of the Supreme Court and the Court of Appeals of the District of Columbia. That District, unlike the Territories, is not in a mere period of transition, expecting soon to become a self-governing State. It has a large population, and that population ought to receive as complete protection as any other part of the Union. It ought, therefore, to be possible for Congress to establish a constitutional court in the District of Columbia, whose judges, like the judges of the other inferior Federal courts, can be removed from office only by the abolition of the court itself. There is much indication in the laws establishing these courts that Congress actually intended to accomplish this result.

A peculiar court recently establishe ${ }^{16}$ for a temporary period has also an unsettled status. This is the Court of Private Land Claims, established for the ascertainment and confirmation, under the Treaty of Guadalupe Hidalgo, of Mexican land grants within the territories of New Mexico, Arizona and Utah, and the States of Nevada, Colorado and Wyoming. The law establishing the court provided that it should expire December 3I, 1895, and the terms of the judges were to expire with the court. The court was given a limited term because the work for which it

26 McAllister $\dot{v}$. United States, I4I U. S. 174, and auth. cit.

${ }^{16}$ Act of March 3, 1891, c. 539. 
was established was expected by that time to be completed. Doubts have been expressed as to the constitutionality of this legislation, especially with respect to the three States mentioned. Jurisdiction over the Territories has been sustained under the territorial clause of the Constitution. ${ }^{17}$ The writer is unable to perceive why it is not sustainable as to the States also. The court does not exercise that branch of judicial power which can be granted under the judiciary article of the Constitution alone. The cases which it adjudicates are claims against the United States, and are for the legislative branch of the Government to decide, unless the jurisdiction be deputed. $^{18}$ Moreover, the terms of the judges were made to run until the expiration of the court, and, since Congress can abolish inferior courts as well as institute them, there seems no reason why a court should not be instituted for a limited term, to dispose of some temporary class of business.

III. Quasi-Judicial Officers.-Chief-Justice Taney in his last opinion said: "The Constitution of the United States delegates no judicial power to Congress. Its powers are confined to legislative duties." "' There is, however, a great deal of power in Congress which is judicial in its essence; the power, namely, to hear and decide claims against the United States itself. However complete may be the analogy between such claims and similar demands against an individual, they have never been regarded as coming within the judiciary article of the Constitution or the Bill of Rights. ${ }^{20}$

In early days such claims could only be presented to Congress, and always required special legislation. They are still adjudicated sometimes by a special act; but more often they are heard and decided by the forms of judicial procedure. For this purpose, in 1855 a judicial or quasi-judicial body was established by Congress under the name of the Court of Claims, ${ }^{11}$ and its jurisdiction has since then from time to time been enlarged. Its judges, according to the terms of the statute, are to hold office during good behavior, but whether or not these statutory provisions are repealable is an undecided question. The tribunal might equally well have been styled the Board of Claims, and

17 United States $v$. Coe, 155 U. S. 76.

18 Astiazaran v. Santa Rita Land and Mining Co., I48 U. S. 80, and auth. cit.

10 Gordon v. United States, 117 U. S. 697, 705.

20 McElrath $v$. United States, 102 U. S. 426, 440.

"Act of Feb 24, 1855, ch. 122. 
its members styled commissioners or auditors. In essence its work is nowise different from that of the accounting officers of the Treasury. As remarked by Chief-Justice Taney: "Neither of them possesses judicial power in the sense in which those words are used in the Constitution. The circumstance that one is called a court and its decisions called judgments cannot alter its character nor enlarge its power." "2s Yet, as already remarked, a hearing and decision by such a court is strictly judicial in nature when Congress does permit the United States to be sued; and when its decision is unreviewable by the executive it may be made reviewable by the superior courts. Hence, although the Chief-Justice rightly said that the Supreme Court's power "is exclusively judicial, and it cannot be required or authorized to exercise any other," ${ }^{23}$ nevertheless that court for thirty years past has had and constantly exercised power to review decisions of the Court of Claims when appealed: and by the recent Tucker Act $^{24}$ the Circuit and District Courts of the United States now exercise a jurisdiction concurrent with that of the Court of Claims. As the latter is not a constitutional court, it may be, and often is, charged with the duty of investigating questions of fact and law for the benefit of Congress or of executive officers, who are not bound to act upon its conclusions. Claims against the United States come commonly first before one of the Auditors of the Treasury; then on appeal before the Comptroller of the Treasury; then by petition before the Court of Claims or a Circuit or District Court; and, finally, before the Supreme Court or the Circuit Court of Appeals. It was recognized by Madison in the first Congress that such duties, when cast upon the Comptroller, are as judicial in nature as those of the courts, and for this reason he endeavored to obtain legislation giving the Comptroller a tenure during good behavior. "25

Another quasi-judicial tribunal, passing upon questions as to which the United States is one of the parties interested, is the Board of General Appraisers sitting at New York. The decisions of this Board as to the valuation of imported goods are final; upon questions of classification they are subject to review by the courts. Their opinions are printed in the Treasury publication entitled "Synopsis of Decisions."

2 Gordon v. United States, supra, at p. 699.

Ibid. at p. 700 .

26 Act of March 3, 1887, c. 359 .

2s Annals of Congress, June 29, I759, pp. 611, 6r4. 
Other claims or quasi-claims against the United States, whose disposition is under the control of Congress, have been referred by general laws to executive officers, who decide them by judicial methods. Among the various classes of pecuniary claims against the Government, by far the largest number are claims for pensions. These arise from acts of congress which are based upon the war power. They are passed upon by the Commissioner of Pensions, subject to review by the Secretary of the Interior. Congress also has the right to dispose of the public lands of the United States. This power, by general laws, has been dcputed to the officers of the General Land Office, subject to review by the Secretary of the Interior. Claims to public lands based upon treaty provisions are sometimes placed by Congress in the hands of tribunals specially constituted, such as the well-known Board of Land Commissioners in California, and the Court of Private Land Claims above mentioned. Applications for letters patent by inventors are passed upon by the Commissioner of Patents, whose decisions thereon are not reviewable by any executive officer. 'The opinions rendered in pension, land and patent cases are regularly reported.

These powers have also been exercised directly by Congress itself through special legislation-including that of granting patents for inventions. ${ }^{26}$ Yet even this porver is so judicial in nature that a direct appeal is allowed from the decisions of the Commissioner to the courts of the District of Columbia ; ${ }^{27}$ or a bill in equity may be filed in any United States Court, in case the applicant is unsuccessful upon appeal, praying an adjudication that he is entitled to a patent. ${ }^{3}$ Contrariwise, as has been already pointed out, rulings of the judges in similar instances have often been made reviewable by executive officers, and the constitutionality of such legislation has never yet been overthrown by a decision of the Supreme Court.

Decisions of these quasi-judicial officers, when acting within their jurisdiction, are, as a rule, unreviewable by the courts. They rank, however, no higher than the decisions of courts of limited jurisdiction, and when the officer has passed the bounds of his jurisdiction in rendering a decision, it is void or voidable."

\footnotetext{
28 Act of Jan. 21, 1803, c. 13.

${ }^{27}$ Act of Feb. 9, 1893, c. 74, \$ 9 .

${ }^{28}$ Rev. St., S 4915 ; Gandy v. Marble, 122 U. S. 432.

Noble $v$. Union River Logging R. R., 147 U. S. 165,173 ; Mullan $v$. United States, 118 U. S. 27I; Butterworth v. Hoe, 112 U. S. 50.
} 
It is also binding only upon the claimant, the United States, and parties claiming under them. Thus, a person claiming prior title is not bound by decisions of the General Land Office, but may bring suit in equity to compel a conveyance of the land thus granted. ${ }^{\circ}$

In some of the bureaus at Washington these decisions are but nominally made by the officer to whom the case is confided by Congress. His signature stands for work performed entirely by the clerical force of his office. This is unavoidable. The work is so immense that it must be divided up among very many persons. Decisions are thus made by mere clerks which affect vast property interests and would well deserve the attention of high judicial tribunals. Systems of appeal within the departments for the same reason fail to effectuate their purpose. Thus the Attorney General, joined with the Secretary of the Interior, "acting as a board," was given certain appellate jurisliction over the Commissioner of the General Land Office," but through press of other business his personal attention is an absolute impossibility. A bill was recently introduced in Congress for a court of departmental appeals, that these cases might be actually decided by the men whose names are affixed to the decisions, and that these men should be of greater standing in the community; but it met with no favor.

The system of adjudication by clerks has reached its most formidable development in the Pension Office. All pension certificates are supposed to be over the signature of the Commissioner of Pensions, and in theory represent adjudications made by him as a special quasi-judicial tribunal. As a matter of fact, the work is done by an immense clerical force. Thus during the fiscal year ending June 30,1892 , the number of pension applications passed upon was $459,6 \mathrm{rr}$. This represented about 1,500 for every working day, and, as the working day in Washington is only six and one-half hours long, represented one "adjudication" every fifteen seconds. In fact, the Commissioner did not even sign his name. It was affixed to the certificate by a rubber stamp. These clerical "adjudications," made largely upon ex-parte statements, have recently been much referred to with veneration such as is given to decrees of a Lord Chancellor. Bills have been pressed in Congress to render them unreviewable except upon proof of actual fraud, even this issue to be left to the slow

* Widdicombe v. Childers, 124 U. S. 400, 405.

31 Rev. St, \& 2451 . 
processes of an action at law. Claims have been pressed in the courts that the present legislation has this effect. A test case was decided adversely to this contention in June, 1895 , by the Court of Appeals of the District of Columbia. ${ }^{33}$ The decision came up for review in the Supreme Court of the United States, where Mr. James C. Carter appeared (as was understood) on behalf of the great organization known as the Grand Army of the Republic. Other important questions also were involved in the case. The Supreme Court ordered a reargument, and before it was again reached the proceeding abated by the appointment of the defendant, Commissioner Lochren, to the position of United States Judge for the District of Minnesota. No proceeding has been instituted against his successor, and this interesting question thus remains unsettled.

The limits of this article will not admit of further illustrations, but it is believed that enough has been said to show that the bounclary between the executive and judicial work of the Government affords interesting ground for exploration.

Edward B. Whituey.

s2 Lochren v. Long, 6 App. Cas. D. C. $4^{86 .}$ 